\title{
Mike Dulworth on the Power of Connection
}

\author{
Nicholas Vitalari (Elasticity Labs)
}

KEYWORDS: Management of Companies \& Enterprises, Entrepreneurship, Leadership.

Starting with his first business mowing neighbors' lawns, serial entrepreneur Mike Dulworth relished the freedom of being his own boss. He also preferred solitary sports such as tennis and skiing to team-based competition, and when he went out with friends he was always the one who drove. But as he moved into the business world and began building his own companies, Dulworth learned a few tough lessons, including the value of choosing the best team members to help him realize his vision. Today Dulworth's mission is helping people connect better. $\mathrm{He}$ is founder and CEO of Executive Networks, a peer network of hundreds of top human resources executives, that helps them better organize and leverage their online, email and social network presences. He is also the author of "The Connect Effect." In this interview with EIX Editor Nick Vitalari, he shares his own story -- including what he learned from his dad, who was an early and powerful mentor -- and his tips for new entrepreneurs. 